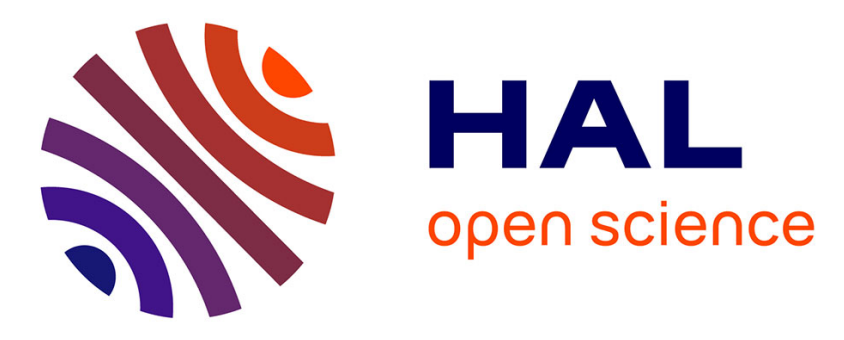

\title{
Charged Dioxomolybdenum(VI) Complexes with Pyridoxal Thiosemicarbazone Ligands as Molybdenum(V) Precursors in Oxygen Atom Transfer Process and Epoxidation (pre)Catalysts
}

Jana Pisk, Biserka Prugovecki, Dubravka Matkovic-Calogovic, Rinaldo Poli, Dominique Agustin, Visnja Vrdoljak

\section{To cite this version:}

Jana Pisk, Biserka Prugovecki, Dubravka Matkovic-Calogovic, Rinaldo Poli, Dominique Agustin, et al.. Charged Dioxomolybdenum(VI) Complexes with Pyridoxal Thiosemicarbazone Ligands as Molybdenum(V) Precursors in Oxygen Atom Transfer Process and Epoxidation (pre)Catalysts. Polyhedron, 2012, 33 (1), pp.441-449. 10.1016/j.poly.2011.12.003 . hal-03156181

\section{HAL Id: hal-03156181 \\ https://hal.science/hal-03156181}

Submitted on 2 Mar 2021

HAL is a multi-disciplinary open access archive for the deposit and dissemination of scientific research documents, whether they are published or not. The documents may come from teaching and research institutions in France or abroad, or from public or private research centers.
L'archive ouverte pluridisciplinaire HAL, est destinée au dépôt et à la diffusion de documents scientifiques de niveau recherche, publiés ou non, émanant des établissements d'enseignement et de recherche français ou étrangers, des laboratoires publics ou privés. 


\title{
Charged Dioxomolybdenum(VI) Complexes with Pyridoxal Thiosemicarbazone Ligands as Molybdenum(V) Precursors in Oxygen Atom Transfer Process and Epoxidation (pre)Catalysts
}

Jana Pisk, ${ }^{\mathrm{a}, \mathrm{b}, \mathrm{c}}$ Biserka Prugovečki, ${ }^{\mathrm{a}}$ Dubravka Matković-Čalogović, ${ }^{\mathrm{a}}$ Rinaldo Poli, ${ }^{\mathrm{c}, \mathrm{d}}$ Dominique Agustin*, b,c Višnja Vrdoljak* a

[a] Laboratory of General and Inorganic Chemistry, Department of Chemistry, Faculty of Science, University of Zagreb, Horvatovac 102 a, HR-10000 Zagreb, Croatia.

E-mail: visnja@chem.pmf.hr.

[b] Université de Toulouse; Institut Universitaire de Technologie Paul Sabatier, Département de Chimie, Av. Georges Pompidou, BP 20258, F-81104 Castres Cedex, France. Email: dominique.agustin@iut-tlse3.fr.

[c] CNRS; LCC (Laboratoire de Chimie de Coordination); Université de Toulouse; UPS, INPT, 205, route de Narbonne, F-31077 Toulouse, France.

[d] Institut Universitaire de France, 103, bd Saint-Michel, F-75005 Paris, France.

\begin{abstract}
The reaction of $\left[\mathrm{MoO}_{2}(\mathrm{acac})_{2}\right]$ with hydrochloric salts of pyridoxal thiosemicarbazone ligands, $\mathrm{H}_{2} \mathrm{~L}^{1-3} \cdot \mathrm{HCl}$, in dry methanol or acetonitrile resulted in the formation of the mononuclear complex $\left[\mathrm{MoO}_{2}\left(\mathrm{HL}^{1}\right)\left(\mathrm{CH}_{3} \mathrm{OH}\right)\right] \mathrm{Cl} \cdot 1.5 \mathrm{CH}_{3} \mathrm{OH} \quad(\mathbf{1 a})$ or polynuclear complexes $\left[\left\{\mathrm{MoO}_{2}\left(\mathrm{HL}^{1-3}\right)\right\} \mathrm{Cl}\right]_{\mathrm{n}} \quad(\mathbf{1 - 3})$ containing a different substituent on the nitrogen atom of the $\mathrm{N}$-thioureide fragment: $\mathrm{Ph}(\mathbf{1}$ and 1a), Me (2) or $\mathrm{H}(3)$. New dinuclear molybdenum(V) complexes $\left[\mathrm{Mo}_{2} \mathrm{O}_{3}\left(\mathrm{HL}^{1-3}\right)_{2}\right] \mathrm{Cl}_{2}$ (4-6) were obtained by oxygen atom abstraction from 1-3 with triphenylphosphine. All compounds were characterized by chemical analysis, IR spectroscopy, one- and two-dimensional NMR methods, TGA and in selected cases by DSC measurements. In addition, the crystal and molecular structure of 1a was determined by single crystal X-ray diffraction. All molybdenum(VI) species were used as (pre)catalysts for olefin epoxidation under solvent-free conditions with a $0.05 \%$ Mo loading vs. olefin.
\end{abstract}

Keywords: Molybdenum/ Thiosemicarbazones / Pyridoxal / Epoxidation / Solvent-free catalysis / OAT 


\section{Introduction}

Oxygen atom transfer (OAT) processes, as well as oxidation processes, are important in Nature and in the chemical industry [1]. Molybdenum enzymes catalyze a number of such reactions. These oxotransferases contain oxo- (or dioxo)-molybdenum units additionally coordinated by sulfur atoms [2]. We are currently interested in dioxomolybdenum(VI) complexes with ligands that mimic the coordination environment of the metal ion in enzymes. Among them, tridentate ligands containing ONS donor atoms are attracting our interest.

Transition metal complexes with thiosemicarbazone ligands are of particular importance because of their interesting biological properties, e.g. antitumoral, antifungal or antiviral properties [3]. Ligands derived from pyridoxal have attracted considerable attention due to different coordination modes to the central metal atom [4-8]. In these complexes, the pyridoxal thiosemicarbazone ligand can be in neutral $\left(\mathrm{H}_{2} \mathrm{~L}\right)$, singly-deprotonated (HL) $)^{-}$, or doubly-deprotonated $(\mathrm{L})^{2-}$ form [4]. The protonation state of these ligands in metal complexes plays an important role since it offers fine-tuning of properties such as electrochemical, photophysical or catalytic activity [9]. Although numerous transition metal complexes $(\mathrm{Cu}, \mathrm{Fe}, \mathrm{Ni}, \mathrm{Mn}, \mathrm{Co})[8 \mathrm{a}, 10]$ with pyridoxal thiosemicarbazone derivatives are known, related molybdenum complexes are scarce [11]. $\mathrm{Mo}^{\mathrm{VI}}$ complexes are also known to be very active as epoxidation catalysts, generally in solution of an organic solvent, especially for neutral complexes [12]. We have recently demonstrated that these epoxidation reactions show very good results under solventfree conditions [13].

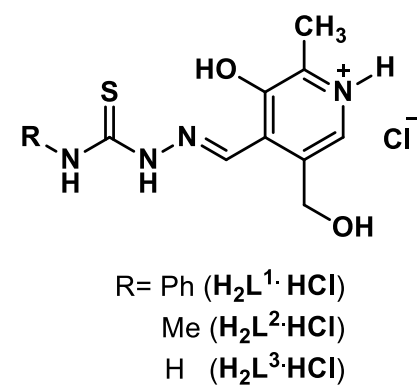

Scheme 1. Pyridoxal based ligands.

In this contribution, we present the syntheses and characterization of dioxomolybdenum(VI) complexes with different pyridoxal thiosemicarbazone charged ligands (Scheme 1), as well as their activity as OAT agents and as epoxidation catalysts under solvent-free conditions. The influence of protonation on the spectroscopic and structural properties of the metal complexes was studied by UV-Vis and NMR spectroscopies, as well as by a single crystal X-ray diffraction. 


\section{Experimental Section}

\subsection{Measurements.}

Thermogravimetric (TG) analyses were performed using a Mettler TG 50 thermobalance with aluminum crucibles. All experiments were recorded with a heating rate of $5{ }^{\circ} \mathrm{C} \mathrm{min}^{-1}$ in a dynamic atmosphere with a flow rate of $200 \mathrm{~cm}^{3} \mathrm{~min}^{-1}$. Differential scanning calorimetry (DSC) measurements were carried out with a Mettler-Toledo DSC823e calorimeter and analyzed by the Mettler STARe 9.01. software. Infrared spectra were recorded in $\mathrm{KBr}$ pellets with a Perkin-Elmer 502 spectrophotometer in the $4500-450 \mathrm{~cm}^{-1}$ region. Electronic absorption spectra were recorded at $25^{\circ} \mathrm{C}$ on a Cary $100 \mathrm{UV} / \mathrm{Vis}$ spectrophotometer. Magnetic measurements were made by the standard Gouy method. NMR spectra were obtained using a Bruker Avance DRX500 spectrometer. The spectra were recorded in DMSO-d ${ }^{6}$ with TMS as internal standard. ${ }^{1} \mathrm{H}$ and ${ }^{13} \mathrm{C}$ resonances were assigned by the combination of $1 \mathrm{D}\left({ }^{1} \mathrm{H}\right.$ and APT sequences) and 2D homo- and heteronuclear experiments (COSY, HSQC and HMBC sequences). Elemental analyses (C, H, N, S) were provided by the Analytical Services Laboratory of the Ruđer Bošković Institute, Zagreb. Chlorine was determined by the gravimetric method as silver chloride [14].

\subsection{Starting materials}

The starting complex $\left[\mathrm{MoO}_{2}(\mathrm{acac})_{2}\right]$ was prepared as described in the literature [15]. Acetonitrile was dried over $\mathrm{P}_{2} \mathrm{O}_{5}$ and then distilled. Methanol was dried using magnesium turnings and iodine, and then distilled. Pyridoxal hydrochloride, thiosemicarbazides $\left(\mathrm{H}_{2} \mathrm{NNHC}(\mathrm{S}) \mathrm{NHR}, \mathrm{R}=\mathrm{C}_{6} \mathrm{H}_{5}, \mathrm{CH}_{3}\right.$ or $\left.\mathrm{H}\right)$ and triphenylphosphine $\left(\mathrm{PPh}_{3}\right)$ were commercially available. Ligands $\mathrm{H}_{2} \mathrm{~L}^{1-3} \cdot \mathrm{HCl}$ were prepared according to procedures described in the literature [16].

\subsection{Synthesis of $\left[\mathrm{MoO}_{2}\left(\mathrm{HL}^{1}\right)\left(\mathrm{CH}_{3} \mathrm{OH}\right)\right] \mathrm{Cl} \cdot 1.5 \mathrm{CH}_{3} \mathrm{OH}(\mathbf{1 a})$}

A mixture of $\left[\mathrm{MoO}_{2}(\mathrm{acac})_{2}\right](0.16 \mathrm{~g}, 0.5 \mathrm{mmol})$ and pyridoxal 4-phenylthiosemicarbazone hydrochloride $\mathrm{H}_{2} \mathrm{~L}^{1} \cdot \mathrm{HCl}(0.14 \mathrm{~g}, 0.4 \mathrm{mmol})$ in dry acetonitrile $(10 \mathrm{~mL})$ and dry methanol $(10 \mathrm{~mL})$ was refluxed for 5 hours. The solution was left at room temperature for one day and the obtained orange crystalline precipitate was filtered, rinsed with acetonitrile and dried in a desiccator down to constant weight. Yield: 0.14 g (55\%). Anal. Calc. for $\mathrm{C}_{17.5} \mathrm{H}_{25} \mathrm{ClMoN}_{4} \mathrm{O}_{6.5} \mathrm{~S}\left(\mathrm{M}_{\mathrm{r}}=558.868\right): \mathrm{C}, 37.61 ; \mathrm{H}, 4.50 ; \mathrm{Cl}, 6.34 ; \mathrm{N}$, 10.03; S, 5.74\%. Found: C, 37.73; H, 3.95; Cl, 6.55; N, 10.56; S, 6.05\%. TG: $\mathrm{CH}_{3} \mathrm{OH}, 13.9 \%$ (Calcd. 14.3\%); $\mathrm{MoO}_{3}, 26.5 \%$ (Calcd. 26.5\%). Selected IR data $\left(\mathrm{cm}^{-1}\right): 1602,1553(\mathrm{C}=\mathrm{N}), 1367(\mathrm{C}-\mathrm{O}), 939$ $\left(\mathrm{MoO}_{2}\right)_{\text {asym }}, 904\left(\mathrm{MoO}_{2}\right)_{\text {sym }}, 639(\mathrm{C}-\mathrm{S})$. 


\subsection{Synthesis of $\left[\left\{\mathrm{MoO}_{2}(\mathrm{HL})\right\} \mathrm{Cl}\right]_{n}$ complexes}

The appropriate pyridoxal thiosemicarbazone ligand $\mathrm{H}_{2} \mathrm{~L}^{1-3} \mathrm{HCl}(0.4 \mathrm{mmol})$ was dissolved in dry acetonitrile $(20 \mathrm{~mL}),\left[\mathrm{MoO}_{2}(\mathrm{acac})_{2}\right](0.16 \mathrm{~g}, 0.5 \mathrm{mmol})$ was added and the resulting solution was refluxed for the specified time. The precipitate that formed was filtered, washed with acetonitrile and dried in a desiccator down to constant weight.

$\mathbf{R}=\mathbf{P h}$ : Complex $\left[\left\{\mathrm{MoO}_{2}\left(\mathrm{HL}^{1}\right)\right\} \mathrm{Cl}\right]_{\mathrm{n}}(\mathbf{1})$ : Dark red product. Reaction time: 5 hours. Yield: $0.22 \mathrm{~g}$ (94\%). Anal. Calc. for $\mathrm{C}_{15} \mathrm{H}_{15} \mathrm{ClMoN}_{4} \mathrm{O}_{4} \mathrm{~S}(\mathrm{Mr}=478.76)$ : C, 37.63; H, 3.16; Cl, 7.41; N, 11.70; S, 6.70\%. Found: C, 37.41; H, 3.11; Cl, 7.14; N, 11.80; S, 6.32\%. TG: $\mathrm{MoO}_{3}, 29.8 \%$ (Calcd. 30.1\%). Selected IR data $\left(\mathrm{cm}^{-1}\right)$ : 1604, $1557(\mathrm{C}=\mathrm{N}), 1362(\mathrm{C}-\mathrm{O}), 954\left(\mathrm{MoO}_{2}\right)_{\text {asym }}, 935\left(\mathrm{MoO}_{2}\right)_{\text {sym }}, 641(\mathrm{C}-\mathrm{S})$. UV-VIS(methanol): $\lambda / \mathrm{nm}\left(\varepsilon / \mathrm{dm}^{3} \mathrm{~mol}^{-1} \mathrm{~cm}^{-1}\right): 354$ (14888) and 434 (8368).

$\mathbf{R}=$ Me: Complex $\left[\left\{\mathrm{MoO}_{2}\left(\mathrm{HL}^{2}\right)\right\} \mathrm{Cl}\right]_{\mathrm{n}}(\mathbf{2})$ : Brown product. Reaction time: 12 hours. Yield: $0.087 \mathrm{~g}$ (43\%). Anal. Calc. for $\mathrm{C}_{10} \mathrm{H}_{13} \mathrm{ClMoN}_{4} \mathrm{O}_{4} \mathrm{~S}(\mathrm{Mr}=416.69)$ : C, 28.82; H, 3.14; Cl, 8.51; N, 13.45; S, 7.70\%. Found: C, 28.66; H, 3.25; Cl, 8.21; N, 13.50; S, 7.65\%. TG: MoO3, 34.3 (Calcd. 34.5\%). Selected IR data $\left(\mathrm{cm}^{-1}\right)$ : 1591, $1540(\mathrm{C}=\mathrm{N}), 1358(\mathrm{C}-\mathrm{O}), 930(\mathrm{Mo}=\mathrm{O}), 801(\mathrm{Mo}=\mathrm{O} \cdots \mathrm{Mo}), 621(\mathrm{C}-\mathrm{S})$. UV-VIS(methanol): $\lambda / \mathrm{nm}\left(\varepsilon / \mathrm{dm}^{3} \mathrm{~mol}^{-1} \mathrm{~cm}^{-1}\right): 325$ (17992) and 405 (2336).

$\mathbf{R}=\mathbf{H}$ : Complex $\left[\left\{\mathrm{MoO}_{2}\left(\mathrm{HL}^{3}\right)\right\} \mathrm{Cl}\right]_{\mathrm{n}}(3)$ : Dark brown product. Reaction time: 12 hours. Yield: $0.08 \mathrm{~g}$ (46 \%). Anal. Calc. for $\mathrm{C}_{9} \mathrm{H}_{11} \mathrm{ClMoN}_{4} \mathrm{O}_{4} \mathrm{~S}(\mathrm{Mr}=402.66)$ : C, 26.85; H, 2.75; Cl, 8.80; N, 13.91; S, 7.96\%. Found: C, 26.53; H, 2.92; 8.54; N, 13.65; S, 7.18\%. TG: $\mathrm{MoO}_{3}, 35.5 \%$ (Calcd. 35.8\%). Selected IR data $\left(\mathrm{cm}^{-1}\right)$ : 1617, $1559(\mathrm{C}=\mathrm{N}), 1357(\mathrm{C}-\mathrm{O}), 930(\mathrm{Mo}=\mathrm{O}), 815(\mathrm{Mo}=\mathrm{O} \cdots \mathrm{Mo}), 621(\mathrm{C}-\mathrm{S})$. UV-VIS(methanol): $\lambda / \mathrm{nm}\left(\varepsilon / \mathrm{dm}^{3} \mathrm{~mol}^{-1} \mathrm{~cm}^{-1}\right): 342(177500)$ and 427 (1927).

\subsection{X-Ray Crystallography.}

The single-crystal X-ray diffraction data of $\mathbf{1 a}$ was collected by $\omega$-scans on an Oxford Diffraction Xcalibur 3 CCD diffractometer with graphite-monochromated Mo-K $\alpha$ radiation $(\lambda=$ $0.71073 \AA$ ). The data reduction was performed using the CrysAlis software package [17]. Solution, refinement and analysis of the structure were done using the programs integrated in the WinGX system [18]. The structure was solved using SHELXS [19] by the Patterson method. The refinement procedure was performed by the full-matrix least-squares method based on $\mathrm{F}^{2}$ against all reflections using SHELXL-97 [20]. One methanol molecule was found to be disordered over two sites and over a center of symmetry. The geometry of the two disordered methanol molecules were restrained to be as that of the methanol that is not disordered. The occupancy of the two sites refined to $0.263(8)$ and $0.237(8)$, 
while they had a common temperature factor. The non-hydrogen atoms were refined anisotropically, except for those of the disordered methanol molecule which were refined isotropically. All hydrogen atoms, except those on the disordered methanol molecule, were located in the difference Fourier maps. Because of poor geometry for some of them they were placed in calculated positions and refined using the riding model. Only the hydrogen atoms of one free and the bound methanol hydroxyl group were fixed. Geometrical calculations were done using PLATON [21]. The structure drawings were prepared using PLATON and MERCURY [22] programs. The crystallographic data are summarized in Table 1, whereas the selected bond distances and angles are listed in Table 2.

Table 1. Crystallographic data for compound 1a.

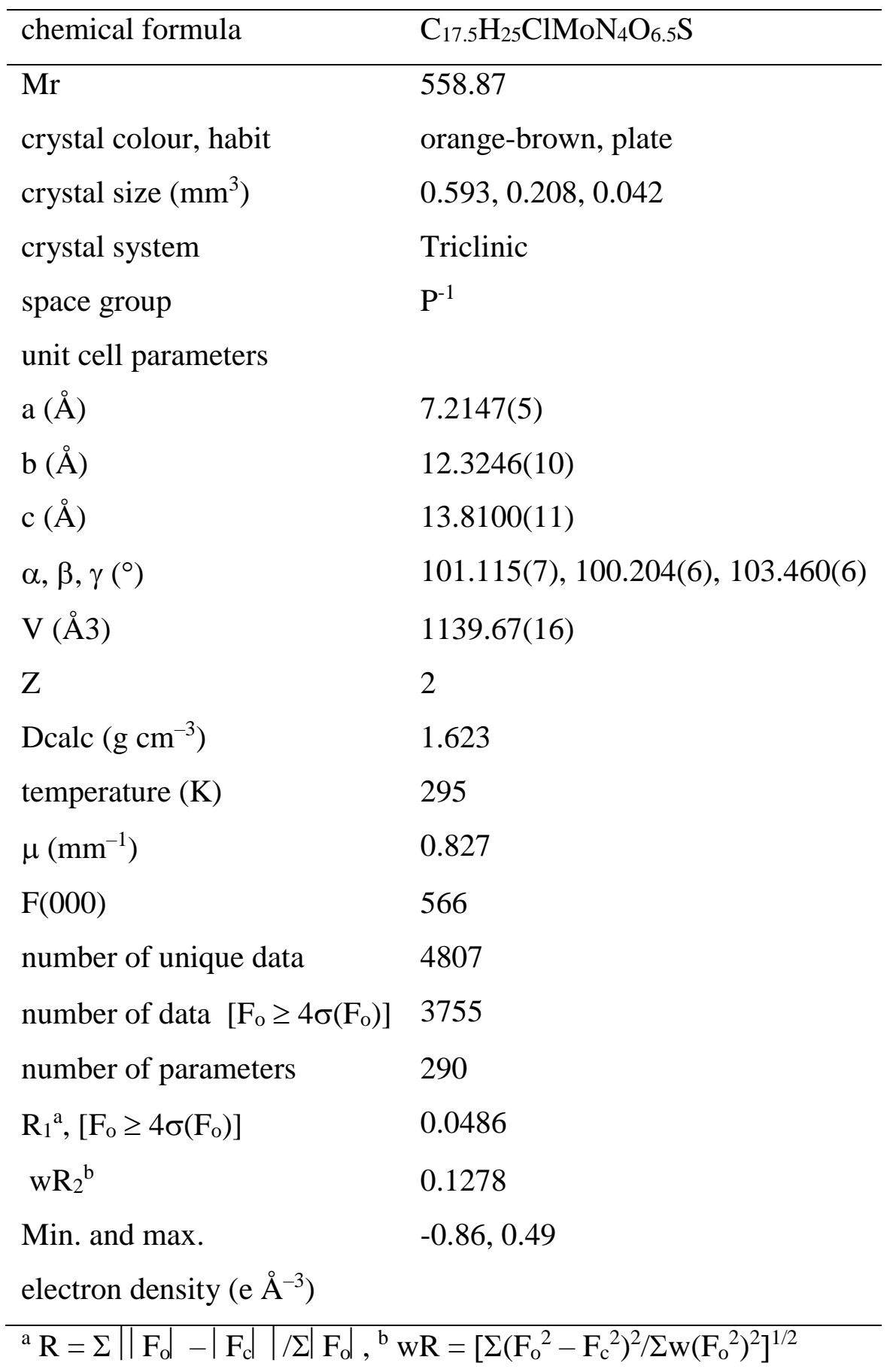




\subsection{Reaction of complexes 1-3 with $\mathrm{PPh}_{3}$}

All reactions were performed under a dry argon atmosphere. $\mathrm{PPh}_{3}(0.02 \mathrm{~g}, 0.08 \mathrm{mmol})$ and $\gamma$-picoline $(8 \mu \mathrm{L})$ were dissolved in dry acetonitrile $(15 \mathrm{~mL})$ and then $\mathbf{1}, \mathbf{2}$ or $\mathbf{3}(0.08 \mathrm{mmol})$ was added. The suspension was heated for $10 \mathrm{~h}$. The dark red-brown microcrystalline product was collected by filtration, washed with acetonitrile and dried.

$\mathbf{R}=\mathbf{P h}$ : Complex $\left[\mathrm{Mo}_{2} \mathrm{O}_{3}\left(\mathrm{HL}^{1}\right)_{2}\right] \mathrm{Cl}_{2}$ (4): Yield: $0.020 \mathrm{~g}$ (52\%) (obtained from 1). Anal. Calcd. for $\mathrm{C}_{30} \mathrm{H}_{30} \mathrm{Cl}_{2} \mathrm{Mo}_{2} \mathrm{~N}_{8} \mathrm{O}_{9} \mathrm{~S}_{2}(\mathrm{Mr}=941.52): \mathrm{C}, 38.27 ; \mathrm{H}, 3.21 ; \mathrm{Cl}, 7.53 ; \mathrm{N}, 11.90 ; \mathrm{S}, 6.81$. Found: C,38.11; H, 3.42; Cl, 7.21; N, 11.85; S, 6.55. TG: $30.8 \% \mathrm{MoO}_{3}$ (Calcd. 30.6\%). Selected IR data $\left(\mathrm{cm}^{-1}\right.$ ): 1601, 1552 $(\mathrm{C}=\mathrm{N}), 1363(\mathrm{C}-\mathrm{O}), 948(\mathrm{Mo}=\mathrm{O}), 788(\mathrm{Mo}-\mathrm{O}-\mathrm{Mo}), 625(\mathrm{C}-\mathrm{S})$.

$\mathbf{R}=$ Me: Complex $\left[\mathrm{Mo}_{2} \mathrm{O}_{3}\left(\mathrm{HL}^{2}\right)_{2}\right] \mathrm{Cl}_{2}$ (5) : Yield: $0.015 \mathrm{~g}(46 \%)$ (obtained from 2). Anal. Calcd. for $\mathrm{C}_{20} \mathrm{H}_{26} \mathrm{Cl}_{2} \mathrm{Mo}_{2} \mathrm{~N}_{8} \mathrm{O}_{7} \mathrm{~S}_{2}(\mathrm{Mr}=817.38): \mathrm{C}, 29.39 ; \mathrm{H}, 3.21 ; \mathrm{Cl}, 8.67 ; \mathrm{N}, 13.71 ; \mathrm{S}, 7.85$. Found: C, 29.24; H, 3.68; Cl, 8.23; N, 13.64; S, 7.66. TG: $35.0 \% \mathrm{MoO}_{3}$ (Calcd. 35.2\%). Selected IR data $\left(\mathrm{cm}^{-1}\right)$ : 1606, 1553 $(\mathrm{C}=\mathrm{N}), 1366(\mathrm{C}-\mathrm{O}), 953(\mathrm{Mo}=\mathrm{O}), 783(\mathrm{Mo}-\mathrm{O}-\mathrm{Mo}), 611(\mathrm{C}-\mathrm{S})$.

$\mathbf{R}=\mathbf{H}$ : Complex $\left[\mathrm{Mo}_{2} \mathrm{O}_{3}\left(\mathrm{HL}^{3}\right)_{2}\right] \mathrm{Cl}_{2}(\mathbf{6})$ : Yield: $0.013 \mathrm{~g}$ (41 \%) (obtained from 3). Anal. Calcd. for $\mathrm{C}_{18} \mathrm{H}_{22} \mathrm{Cl}_{2} \mathrm{Mo}_{2} \mathrm{~N}_{8} \mathrm{O}_{7} \mathrm{~S}_{2}(\mathrm{Mr}=789.33): \mathrm{C}, 27.39 ; \mathrm{H}, \mathrm{Cl}, 8.98 ; 2.81 ; \mathrm{N}, 14.20 ; \mathrm{S}, 8.12$. Found: C, 27.25; H, 3.10; Cl, 8.65; N, 14.12; S, 7.98. TG: $36.5 \% \mathrm{MoO}_{3}$ (Calcd. 36.5\%). Selected IR data $\left(\mathrm{cm}^{-1}\right): 1617,1560$ $(\mathrm{C}=\mathrm{N}), 1343(\mathrm{C}-\mathrm{O}), 948(\mathrm{Mo}=\mathrm{O}), 779(\mathrm{Mo}-\mathrm{O}-\mathrm{Mo}), 621(\mathrm{C}-\mathrm{S})$.

\subsection{General procedure for the epoxidation of cyclooctene by aqueous TBHP}

A mixture of cyclooctene $(2.76 \mathrm{~mL}, 20 \mathrm{mmol})$, acetophenone $(0.1 \mathrm{~mL}$, internal reference) and Mo (pre)catalyst $(0.01 \mathrm{mmol} \mathrm{Mo})$ was stirred and heated up to $80{ }^{\circ} \mathrm{C}$ before adding aqueous TBHP (70 wt \% , $5.48 \mathrm{~mL}, 40 \mathrm{mmol}$ ). The reaction was followed for $6 \mathrm{~h}$. Aliquots $(0.1 \mathrm{~mL})$ of the organic phase were taken at required times from the reaction media, mixed with $2 \mathrm{~mL}$ of $\mathrm{Et}_{2} \mathrm{O}$ and a small quantity of $\mathrm{MnO}_{2}$ was added. The mixture was then filtered through silica and analyzed by ${ }^{1} \mathrm{H} \mathrm{NMR}$ in $\mathrm{CDCl}_{3}$.

\subsection{Computational Details}

All geometries were optimized without any symmetry constraint with the Gaussian 03 program suite [23]. The input geometries were adapted from the X-ray structures of $\left[\mathrm{MoO}_{2}\left(\mathrm{~L}^{1}\right)(\mathrm{MeOH})\right] \cdot \mathrm{CH}_{3} \mathrm{OH}\left(\mathbf{1 a}^{*}\right)$ [11] and $\left[\mathrm{MoO}_{2}\left(\mathrm{HL}^{1}\right)(\mathrm{MeOH})\right] \mathrm{Cl} \cdot 1.5 \mathrm{CH}_{3} \mathrm{OH}$ (1a). The calculations used the standard B3LYP three-parameter functional [24] with the 6-31G** basis set [25] for $\mathrm{C}, \mathrm{H}, \mathrm{N}$ and $\mathrm{O}$ atoms and the CEP-31G* basis set [26] for molybdenum. All optimized geometries were confirmed to be local minima by frequency analyses (Table S1 in the Supporting Information). The calculated IR spectra were 
generated from the DFT-generated frequencies and intensities by applying Lorentzian functions and adjusting the linewidth to the best fit with experimental spectra.

\section{Results and Discussion}

New mononuclear $\left[\mathrm{MoO}_{2}\left(\mathrm{HL}^{1}\right)\left(\mathrm{CH}_{3} \mathrm{OH}\right)\right] \mathrm{Cl} \cdot 1.5 \mathrm{CH}_{3} \mathrm{OH}$ (1a), and polynuclear molybdenum(VI) complexes $\left[\left\{\mathrm{MoO}_{2}\left(\mathrm{HL}^{1-3}\right)\right\} \mathrm{Cl}\right]_{\mathrm{n}}(\mathbf{1 - 3})$ were prepared by the reaction of $\left[\mathrm{MoO}_{2}(\mathrm{acac})_{2}\right]$ with different pyridoxal thiosemicarbazone hydrochlorides (Scheme 2). Dry solvents (methanol and acetonitrile) were used to prevent ligand hydrolysis.

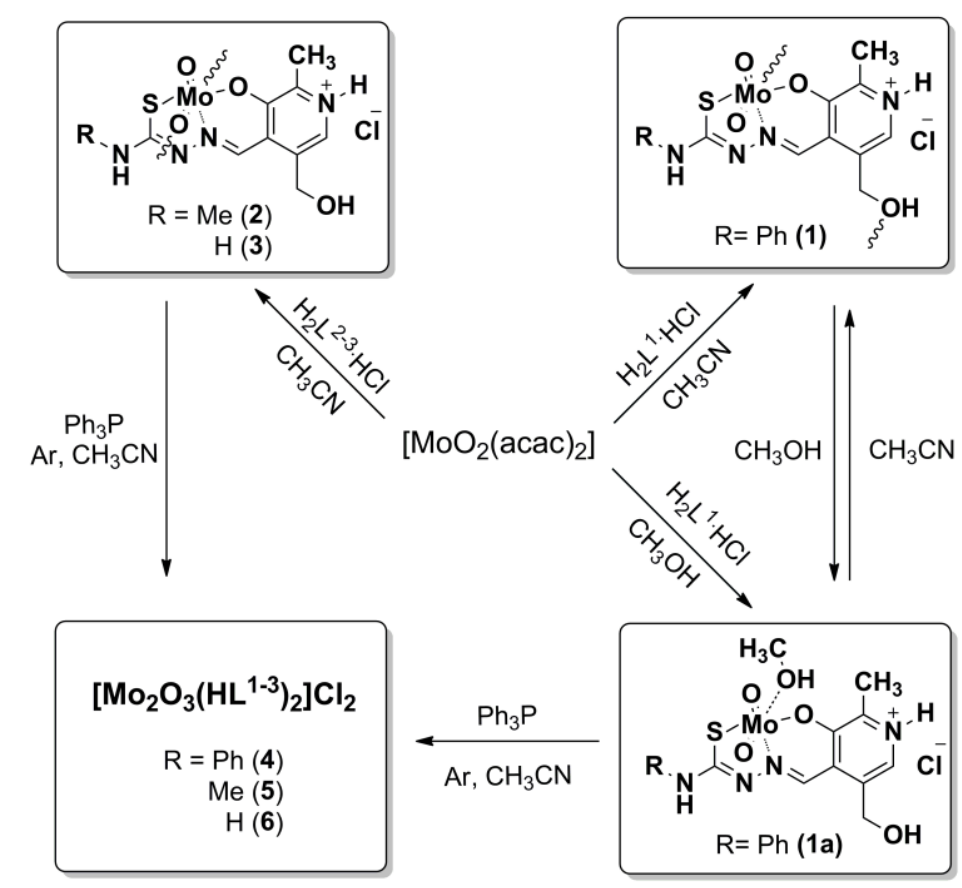

Scheme 2. Synthesis of $\mathrm{Mo}^{\mathrm{VI}}$ complexes (1a and 1-3) and $\mathrm{Mo}^{\mathrm{V}}$ complexes (4-6).

Complexes 1a and 1 were identified by the presence of $v\left(\mathrm{MoO}_{2}\right)$ bands at 939 and $904 \mathrm{~cm}^{-1}$ for $\mathbf{1 a}$, and 954 and $935 \mathrm{~cm}^{-1}$ for 1 [27]. A band around $1071 \mathrm{~cm}^{-1}$ for both complexes was assigned to the $v(\mathrm{C}-\mathrm{O})$ of the coordinated methanol molecule in 1a or the hydroxymethyl group in $\mathbf{1}$ (Scheme 2) [28]. On the other hand, the sixth coordination site in $\left[\left\{\mathrm{MoO}_{2}\left(\mathrm{HL}^{2,3}\right)\right\} \mathrm{Cl}\right]_{\mathrm{n}}(\mathbf{2}$ and $\mathbf{3})$ is occupied by the oxygen atom from the $\mathrm{Mo}=\mathrm{O}$ unit from the neighbouring complex molecule, thus forming a coordination polymer. This is suggested by the intense IR bands observed at $801 \mathrm{~cm}^{-1}(\mathbf{2})$ and $815 \mathrm{~cm}^{-1}(\mathbf{3})$, as well as by a single strong absorption band at $930 \mathrm{~cm}^{-1}$ assigned to the $\mathrm{Mo}=\mathrm{O} \cdots$ Mo bridging and terminal $\mathrm{Mo}=\mathrm{O}$ groups, respectively [29]. The broad absorption bands in the $3000-2600 \mathrm{~cm}^{-1}$ range, appearing in the spectra of all complexes, confirm the presence of the pyridinium moiety. Two vibration bands in the $1610-1540 \mathrm{~cm}^{-1}$ range were assigned to the stretching vibrations of the $\mathrm{C}=\mathrm{N}$ groups of the 
thiosemicarbazones [30], whereas those at about $625 \mathrm{~cm}^{-1}$ were attributed to the coordinated C-S $\mathrm{S}_{\text {thiol }}$ group [31].

Polynuclear complexes 1-3 are not solvated. Upon heating the $\left[\left\{\mathrm{MoO}_{2}\left(\mathrm{HL}^{1-3}\right)\right\} \mathrm{Cl}\right]_{\mathrm{n}}$ complexes under a pure oxygen atmosphere, only weight losses corresponding to complex decomposition occurred in the $227-430{ }^{\circ} \mathrm{C}(\mathbf{1}), 207-457^{\circ} \mathrm{C} \mathrm{(2)}$ and $209-441{ }^{\circ} \mathrm{C} \mathrm{(3)}$ ranges. Crystals of 1a were used for a TG analysis without grinding, to limit the loss of the solvent molecule. The first step in the TGA curve (weight loss within the $25-105^{\circ} \mathrm{C}$ range) was related to the solvent molecule release. Afterward, the intermediate product is stable up to $225{ }^{\circ} \mathrm{C}$ when it starts to decompose and afford $\mathrm{MoO}_{3}$ as the final residue. The mononuclear complex $1 \mathrm{a}$ was heated from ambient temperature up to $175^{\circ} \mathrm{C}$. The substance obtained by this treatment was identified by chemical and TG analyses as the pentacoordinated $\left[\left\{\mathrm{MoO}_{2}\left(\mathrm{HL}^{1}\right)\right\} \mathrm{Cl}\right]$ compound.

Even after prolonged heating of $\mathbf{1 a}$ at $175{ }^{\circ} \mathrm{C}$ in the solid state, the resulting material does not convert into 1. Such thermally induced solid-state reaction is expected to occur only between molecules that are suitably arranged, with reacting centres close to each other within the crystal [32]. In the structure of 1a the hydroxymethyl groups are not sufficiently close to the nearest $\mathrm{Mo}{ }^{\mathrm{VI}}$ centres of the $\left[\mathrm{MoO}_{2}\left(\mathrm{HL}^{1}\right)\right]^{+}$ cations (the $\mathrm{Mo} \cdots \mathrm{O} 2$ distance is $5.483 \AA$, Figure S1) [32]. This was also confirmed by comparison of the IR spectrum of the non solvated product with those observed for 1a and 1 (Figure S2 in the Supporting Information). Also, transformation of $\mathbf{1 a}$ into a $\mu$-oxo bridged dimer is not possible in the solid-state, since the $\mathrm{Mo}=\mathrm{O}_{\mathrm{t}}$ group is not directed toward the vacant coordination site of the neighbouring $\left[\mathrm{MoO}_{2}(\mathrm{HL})\right]^{+}$cation. This is additionally supported by absence of a strong band at $\sim 800 \mathrm{~cm}^{-1}$, which is characteristic for a molybdenum $\cdots$ oxygen interaction.

On the other hand, transformation of the mononuclear complex 1a into the coordination polymer $\mathbf{1}$ can be achieved by dissolution of $\mathbf{1 a}$ in acetonitrile. Similarly, the reverse transformation can be obtained after exposure of the samples of $\mathbf{1}$ to methanol. Depending on the solvent nature, the methanol molecule in $\left[\mathrm{MoO}_{2}\left(\mathrm{HL}^{1}\right)\left(\mathrm{CH}_{3} \mathrm{OH}\right)\right]^{+}$cation can be easily replaced by the hydroxymethyl group of a neighbouring molecule and vice versa as already observed for the related neutral complexes [33].

\subsection{NMR Spectroscopy}

The NMR spectra of compounds 1-3 were recorded in DMSO-d $\mathrm{d}^{6}$ because of their very low solubility in non-coordinating solvents (the numbering scheme is given in Scheme 3 and all data are collected in Table S2, in Supporting Information). The solubilisation of the coordination polymers 1-3 is probably related to the coordination of DMSO to the $\mathrm{Mo}^{\mathrm{VI}}$ center, breaking the infinite chain structure and yielding mononuclear $\left[\mathrm{MoO}_{2}\left(\mathrm{HL}^{1-3}\right)(\mathrm{DMSO})\right]^{+}$complexes. The spectra of $\mathbf{1 a}$ and $\mathbf{1}$ are very similar, the only difference being the presence of the $\mathrm{MeOH}$ molecule signal for the solution of $\mathbf{1 a}$. 


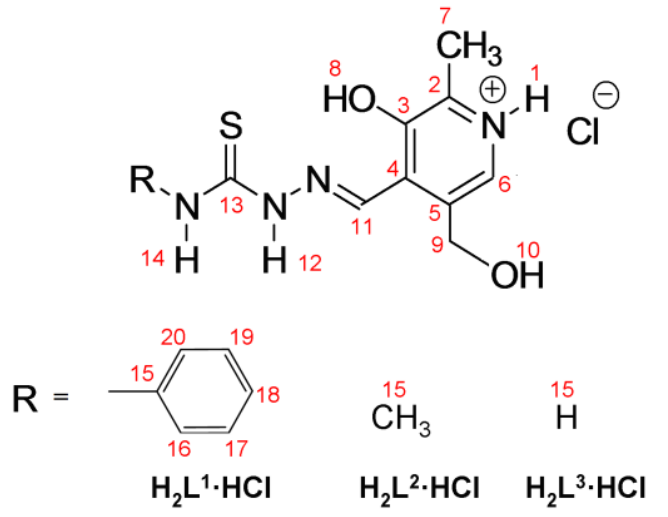

Scheme 3. NMR numbering scheme of $\mathrm{H}_{2} \mathrm{~L}^{1-3} \cdot \mathrm{HCl}$.

${ }^{1} \mathrm{H}$ and ${ }^{13} \mathrm{C}$ chemical shifts are compared with those of the free ligand $\mathrm{H}_{2} \mathrm{~L}^{1-3} \cdot \mathrm{HCl}$. In the ${ }^{1} \mathrm{H}$ spectra of compounds 1-3, the azomethine $\mathrm{CH}=\mathrm{N}$ proton signal $\mathrm{H}_{11}$ is shifted downfield up to $0.23 \mathrm{ppm}$ as a result of the complexation. The absence of signals due to $\mathrm{OH}$ and $=\mathrm{N}-\mathrm{NH}\left(\mathrm{H}_{8}\right.$ and $\mathrm{H}_{12}$, respectively) suggests coordination through the oxygen atom and thioenolization of the $-\mathrm{N}-(\mathrm{C}=\mathrm{S})-$ group into $-\mathrm{N}=(\mathrm{C}-\mathrm{S})-$. Also, the $\mathrm{H}_{14}$ protons exhibit an upfield shift (up to $0.89 \mathrm{ppm}$ ) as a consequence of the coordination through the sulphur atom from the deprotonated thiol group. The ${ }^{13} \mathrm{C}$ chemical shifts exhibit larger changes, up to $7.35 \mathrm{ppm}$ as observed for $\mathrm{C}_{11}$ and $11.49 \mathrm{ppm}$ for $\mathrm{C}_{13}$. These effects are downfield for the former and upfield for the latter site and confirm the coordination of imine-nitrogen and thiol-sulphur atoms to the $\left\{\mathrm{MoO}_{2}\right\}^{2+}$ core. The effects observed for $\mathrm{C}_{3}$ are all downfield and appreciably smaller (up to $1.57 \mathrm{ppm})$.

The ${ }^{1} \mathrm{H}$ and ${ }^{13} \mathrm{C}$ chemical shift values of $\left[\left\{\mathrm{MoO}_{2}\left(\mathrm{HL}^{1-3}\right)\right\} \mathrm{Cl}\right]_{\mathrm{n}}(\mathbf{1 - 3})$ may be compared to those previously reported for the related complexes containing the doubly deprotonated ligands $\left[\mathrm{MoO}_{2}\left(\mathrm{~L}^{1-3}\right)\right]_{\mathrm{n}}(\mathrm{Table} \mathrm{S} 2$ in SI, Figure S3). The spectral variations can be correlated with the protonation of the pyridoxal ligand. The signal at ca. 12 ppm (assigned to $\mathrm{H}_{1}$ ) found in the spectra of compounds $\mathbf{1 - 3}$ is absent in the spectra of $\left[\mathrm{MoO}_{2}\left(\mathrm{~L}^{1-3}\right)\right]_{\mathrm{n}}$. This confirms protonation of the pyridine ring $\mathrm{N}$ atom and the presence of the ligand as (HL) $)^{-}$. Such protonation induces a shift of all pyridine ring signals, particularly those of $\mathrm{H}_{6}$ (up to +0.13 $\mathrm{ppm}$ ) and $\mathrm{C}_{6}$ atoms (up to $-6.15 \mathrm{ppm}$ ). Additionally, the broad signal assigned to the hydroxymethyl $\mathrm{H}_{10}$ proton is also fairly shifted downfield by approximately $0.25 \mathrm{ppm}$. There is also a significant downfield shift of the $\mathrm{H}_{14}$ signal (up to $0.41 \mathrm{ppm}$ ) in complexes 1-3 with respect to the corresponding deprotonated complexes, which is probably the result of hydrogen bonding between the thiosemicarbazone NH group and chloride [34]. This suggests that the chloride counterion maintains this interaction in solution, as also found in the solid state (see next section).

\subsection{X-Ray Crystallography}


In the molecular structure of $\mathbf{1 a}$ the coordination sphere around the Mo atom is a distorted octahedron with a tridentate ligand $\left(\mathrm{HL}^{1}\right)^{-}$bound to the $\operatorname{cis}-\left\{\mathrm{MoO}_{2}\right\}^{2+}$ core. The ligand is coordinated to molybdenum as ONS-donor through the phenolic-oxygen, the imine-nitrogen and the thiol-sulphur atoms. The sixth coordination site is occupied by the methanol molecule. The C1-S bond of 1.737(4) $\AA$ indicates the thiol form. Two chelate rings are formed by complexation of the ligand to Mo, a five- (Mo, $\mathrm{S}, \mathrm{C} 1, \mathrm{~N} 2, \mathrm{~N} 3)$ and a six-membered $(\mathrm{Mo}, \mathrm{N} 3, \mathrm{C} 2, \mathrm{C} 3, \mathrm{C} 7, \mathrm{O} 1)$ chelate ring that form a dihedral angle of $8.70(13)^{\circ}$. Therefore, the ligand is relatively planar with $\pi$-electron delocalization throughout the ligand. The substituted pyridine and phenyl rings form an angle of only 3.9(2) ${ }^{\circ}$. An ORTEP drawing of the complex cation and the chloride anion is shown in Figure 1. Relevant bond lengths and angles are given in Table 2.

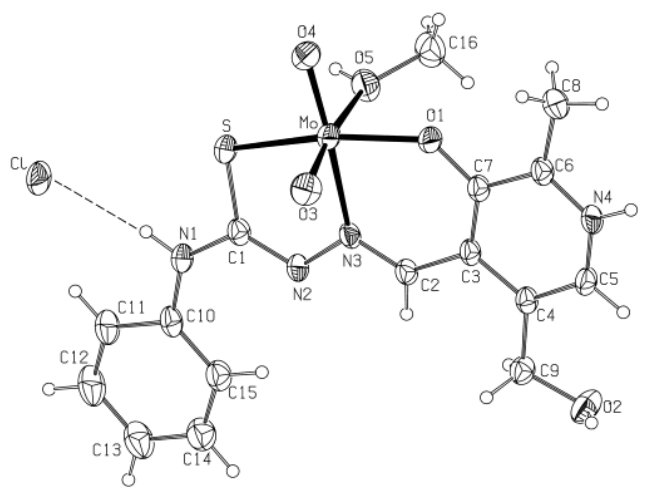

Figure 1. ORTEP plot of the structure of 1a with displacement ellipsoids of non-hydrogen atoms drawn at the $30 \%$ probability level. Molecules of crystal methanol are omitted. Hydrogen bond is shown by a dashed line.

Table 2. Selected bond lengths $(\AA)$ and angles $\left(^{\circ}\right)$ for compound $\mathbf{1 a}$.

\begin{tabular}{llll}
\hline & Bond lengths $(\AA)$ & Bond angles $\left(^{\circ}\right)$ \\
\hline Mo1-S & $2.3936(10)$ & S-Mo-O1 & $149.40(10)$ \\
Mo1-O1 & $1.943(3)$ & S-Mo-O3 & $98.59(10)$ \\
Mo1-O3 & $1.684(4)$ & S-Mo-O4 & $92.97(10)$ \\
Mo1-O4 & $1.696(4)$ & S-Mo-O5 & $79.33(8)$ \\
Mo1-O5 & $2.332(4)$ & S-Mo-N3 & $76.11(7)$ \\
Mo1-N3 & $2.312(4)$ & O1-Mo-O3 & $100.22(14)$ \\
S-C1 & $1.737(4)$ & O1-Mo-O4 & $105.04(13)$ \\
N1-C1 & $1.350(5)$ & O1-Mo-O5 & $77.22(12)$ \\
N1-C10 & $1.407(6)$ & O1-Mo-N3 & $80.84(11)$
\end{tabular}




$\begin{array}{llll}\text { N2-C1 } & 1.318(5) & \text { O3-Mo-O4 } & 105.15(17) \\ \text { N2-N3 } & 1.377(5) & \text { O3-Mo-O5 } & 167.93(15) \\ \text { N3-C2 } & 1.290(4) & \text { O3-Mo-N3 } & 87.45(14) \\ \text { N4-C5 } & 1.319(5) & \text { O4-Mo-O5 } & 86.87(15) \\ \text { N4-C6 } & 1.330(5) & \text { O4-Mo-N3 } & 164.58(13) \\ \text { C2-C3 } & 1.457(4) & \text { O5-Mo-N3 } & 80.50(12)\end{array}$

The crystal structure of $\mathbf{1 a}$ consists of $\left[\mathrm{MoO}_{2}\left(\mathrm{HL}^{1}\right)\left(\mathrm{CH}_{3} \mathrm{OH}\right)\right]^{+}$cations, chloride anions and molecules of methanol of which one is in a general position while the other one is disordered over a center of symmetry. Both protonated nitrogen atoms (N1 and N4) and the hydroxyl group from the pyridoxal moiety $(\mathrm{O} 2)$ are involved in hydrogen bonding with the chloride ion, thus connecting three neighbouring complex cations and forming double-chains along the $c$-axis. The chains are linked through hydrogen bonding with one of the free methanol molecules along the $a$-axis. The solvent methanol molecule that is not disordered is a hydrogen bond acceptor from the bound methanol and a donor to the pyridoxal hydroxyl group. Hydrogen bonds are given in Table 3. Interactions between chains along the $b$-axis involve the disordered methanol molecule. The packing diagram is shown in Figure 2 (and Figure S4 in the Supporting Information).

Table 3. Geometry of the hydrogen bonds $\left(\AA,^{\circ}\right)$ for compound $\mathbf{1 a}$.

\begin{tabular}{lllll}
\hline $\mathrm{D}-\mathrm{H} \cdots \mathrm{A}$ & $\mathrm{D}-\mathrm{H}(\AA)$ & $\mathrm{H} \cdots \mathrm{A}(\AA)$ & $\mathrm{D} \cdots \mathrm{A}(\AA)$ & $\mathrm{D}-\mathrm{H} \cdots \mathrm{A}\left(^{\circ}\right)$ \\
\hline $\mathrm{N} 1-\mathrm{H} 1 \ldots \mathrm{Cla}$ & 0.86 & 2.39 & $3.221(3)$ & 162 \\
$\mathrm{~N} 4-\mathrm{H} 4 \ldots \mathrm{Clb}$ & 0.86 & 2.18 & $3.033(3)$ & 174 \\
$\mathrm{O} 2-\mathrm{H} 2 \mathrm{a} \ldots \mathrm{Cl}$ & 0.82 & 2.30 & $3.105(4)$ & 169 \\
$\mathrm{O} 5-\mathrm{H} 5 \mathrm{a} \ldots \mathrm{O} 6$ & 0.81 & 1.83 & $2.639(5)$ & 175 \\
O6-H6a...O2c & 0.99 & 1.91 & $2.878(6)$ & 164 \\
\hline
\end{tabular}

${ }^{\mathrm{a}} 2-\mathrm{x}, 1-\mathrm{y}, 1-\mathrm{z} ;{ }^{\mathrm{b}} 2-\mathrm{x}, 1-\mathrm{y}, 2-\mathrm{z},{ }^{\mathrm{c}} 1-\mathrm{x}, 1-\mathrm{y}, 1-\mathrm{z}$ 


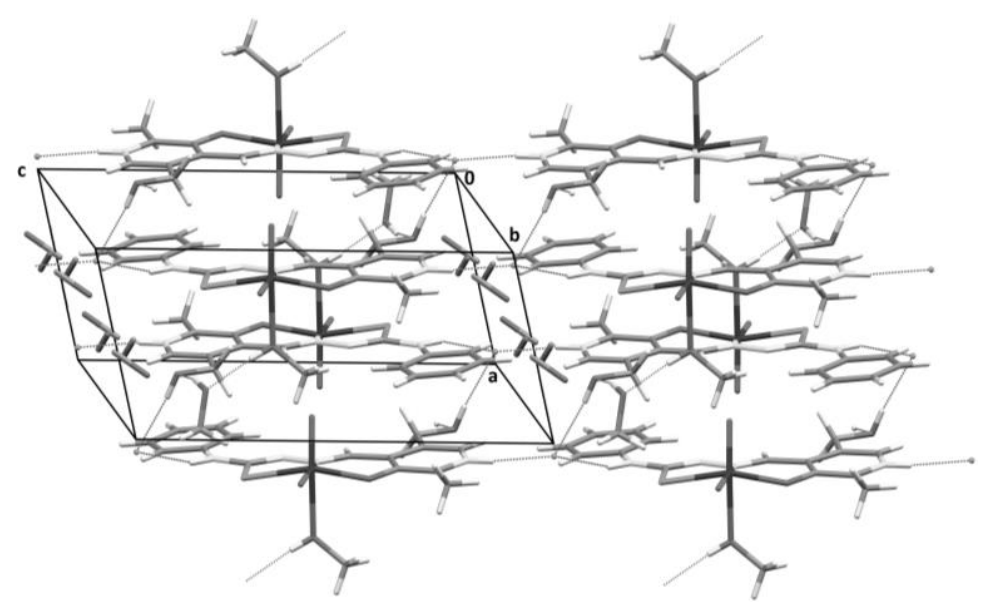

Figure 2. Packing of $\mathbf{1 a}$ in the unit cell. Hydrogen bonds are shown by dotted lines. All four possible molecule sites of the disordered methanol molecule are shown (without their hydrogen atoms).

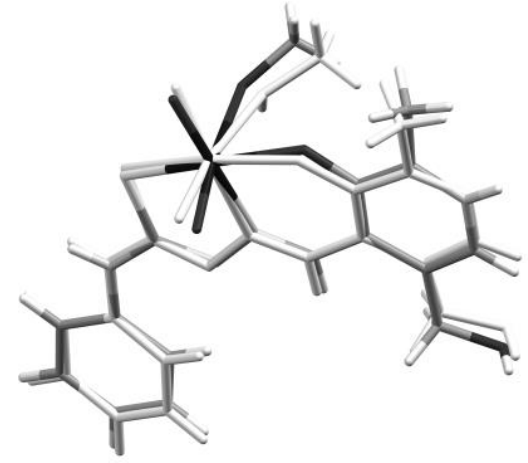

Figure 3. Superimposed molecules of 1a (light grey) and 1a* (dark grey).

In contrast to $\mathbf{1 a}$ where $\mathrm{N} 4$ is a hydrogen bond donor, the same atom in the non protonated complex, $\left[\mathrm{MoO}_{2}\left(\mathrm{~L}_{1}\right)\left(\mathrm{CH}_{3} \mathrm{OH}\right)\right] \cdot \mathrm{CH}_{3} \mathrm{OH}\left(\mathbf{1 a}^{*}\right)$, is a hydrogen bond acceptor [11]. Significant changes in the geometry of $\mathbf{1 a}$ in comparison to $1 \mathbf{a}^{*}$ include angles of the Mo coordination polyhedron and the C5-N4C6 angle in the pyridoxal ring, which increases upon protonation from $119.6(2)^{\circ}$ to $124.6(3)^{\circ}$, Figure 3. The largest difference in the coordination polyhedron concerns the S-Mo-O5 angle, most probably caused by involvement in different hydrogen bonding pattern and also different packing in the crystal.

\subsection{DFT calculations}

DFT geometry optimizations were carried out to assign the IR absorption bands in 1a and 1a*, in order to assess the effect of ligand protonation. Before examining these results, we present a brief description of the optimized geometries. Relevant results are collected and compared to the experimental crystallographic data in Table 4. The agreement between experimental and calculated geometries for the core is generally very good and small differences may be at least in part attributed to crystal packing, which is not accounted for in the single molecule calculation. All calculated distances are overestimated, 
very little for the terminal oxido ligands (maximum deviation $0.01 \AA$ ), to an intermediate degree for Mo$\mathrm{O}(1), \mathrm{Mo}-\mathrm{S}$ and Mo-N (0.03 $\AA$ to $0.06 \AA$ ), and to a greater extent for the coordinated methanol $\mathrm{O}$ atom (by $0.14 \AA$ on average).

Table 4. Comparison of relevant bond lengths $(\AA)$ between experimental data for $\mathbf{1 a}$ and $\mathbf{1 a} *$ and related calculated structures $\left[\mathrm{MoO}_{2}\left(\mathrm{HL}^{1}\right)(\mathrm{MeOH})\right]^{+}(\mathbf{A})$ and $\left[\mathrm{MoO}_{2}\left(\mathrm{~L}^{1}\right)(\mathrm{MeOH})\right]\left(\mathbf{A}^{*}\right)$. For $\mathbf{A}$, only the cation had been taken into account for the calculation. Atom labels refer to the crystallographic structure.

\begin{tabular}{lllll}
\hline Bonds & $\mathbf{1 a}$ & $\mathbf{A}$ & $\mathbf{1 a}^{*}$ & $\mathbf{A}^{*}$ \\
\hline Mo-O(1) & 1.943 & 1.987 & 1.918 & 1.975 \\
Mo-O(3) & 1.684 & 1.691 & 1.689 & 1.693 \\
Mo-O(4) & 1.696 & 1.697 & 1.706 & 1.706 \\
Mo-O(5) & 2.332 & 2.455 & 2.336 & 2.484 \\
Mo-N(3) & 2.312 & 2.373 & 2.280 & 2.339 \\
Mo-S(1) & 2.394 & 2.448 & 2.415 & 2.449 \\
N(3)-N(2) & 1.378 & 1.345 & 1.364 & 1.370 \\
\hline
\end{tabular}

The elongation/shortening of bond lengths experimentally observed between neutral and charged complexes $\left(\mathbf{1 a}^{*}\right.$ and $\left.\mathbf{1 a}\right)$ is reproduced by the DFT calculations, with similar differences. Only the most relevant data is listed in Table 4.

The experimental IR spectra of $\mathbf{1 a}$ and $\mathbf{1} \mathbf{a}^{*}$ are compared with the calculated ones for $\mathbf{A}$ and $\mathbf{A} *$ in Figure 4. Although shifted by around $60 \mathrm{~cm}^{-1}$ on average, the patterns are similar. Three vibrations at 981 (asym), 1006 (sym), 1020 (sym) $\mathrm{cm}^{-1}$ for $\mathbf{A}$ can be attributed to $\mathrm{MoO}_{2}$ (the symmetric vibration is coupled with other vibrations and contributes significantly to two normal modes) and two vibrations at 968 (asym) and 1001 (sym) $\mathrm{cm}^{-1}$ for $\mathbf{A}^{*}$. The calculations are also useful for the assignment of other vibrational modes, such as the C-S vibrations $\left(685 \mathrm{~cm}^{-1}\right.$ for $\mathbf{A}$ and $679 \mathrm{~cm}^{-1}$ for $\left.\mathbf{A}^{*}\right)$ the N-N vibrations $\left(1190 \mathrm{~cm}^{-1}\right.$ for $\mathbf{A}$ and $1152 \mathrm{~cm}^{-1}$ for $\mathbf{A}^{*}$ ), the $\mathrm{CH}=\mathrm{N}$ vibrations (coupled with other vibrations in bands at 1617, 1656 and $1658 \mathrm{~cm}^{-1}$ for $\mathbf{A}$ and at 1560,1624 and $1653 \mathrm{~cm}^{-1}$ for $\mathbf{A}^{*}$ ) and finally the pyridoxal N-H vibration in case of $\mathbf{A}\left(3569 \mathrm{~cm}^{-1}\right)$. The shift relatively to the experimental values is observed in all cases, as typically observed for calculations carried out at this level of theory. 


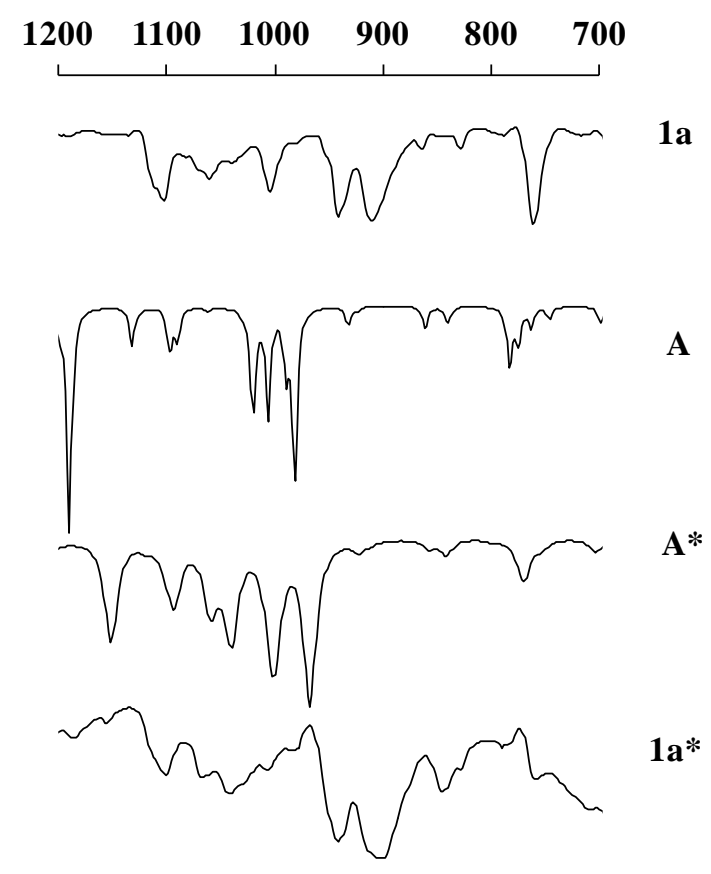

Figure 4. Comparison of experimental (1a and $\left.\mathbf{1} \mathbf{a}^{*}\right)$ and theoretical ( $\mathbf{A}$ and $\mathbf{A} *$ ) IR vibration pattern in the range $700-1200 \mathrm{~cm}^{-1}$.

\subsection{UV-Vis Spectroscopy}

The electronic spectra of the thiosemicarbazone complexes 1-3 recorded in methanol exhibited S(p $\pi)-$ $\operatorname{Mo}(\mathrm{d} \pi)$ LMCT in the regions $405-434 \mathrm{~nm}$ as well as $\mathrm{N}(\mathrm{p} \pi)-\mathrm{Mo}(\mathrm{d} \pi)$ and $\mathrm{O}(\mathrm{p} \pi)-\mathrm{Mo}(\mathrm{d} \pi)$ LMCT bands at 325-354 $\mathrm{nm}$ [35]. These spectral characteristics are influenced by the nature of the ligand and by its degree of protonation. Titrations of 1-3 with $\mathrm{HCl}$ or $\mathrm{Et}_{3} \mathrm{~N}$ were performed by adding aliquots of $\mathrm{HCl}$ or $\mathrm{Et}_{3} \mathrm{~N}$ solution $(2 \mu \mathrm{L})$ into cuvettes in methanol with UV-Vis monitoring and compared with those of the corresponding $\mathrm{H}_{2} \mathrm{~L}^{1-3} \cdot \mathrm{HCl}$ ligands. A titration experiment was also carried out by adding $\mathrm{HCl}$ to $1 \mathbf{a}^{*}$. Spectral changes associated to system 1 and the ligand $\mathrm{H}_{2} \mathrm{~L}^{1} \cdot \mathrm{HCl}$ are presented in Figure 5.

The addition of $\mathrm{HCl}$ to the solution obtained from 1 resulted in a shift of the 434 and $354 \mathrm{~nm}$ bands to higher wavelengths (461 and $363 \mathrm{~nm}$, respectively) with a change of molar absorptivity. These changes are presumably due to the protonation of the ligand and formation of the $\left[\mathrm{MoO}_{2}\left(\mathrm{H}_{2} \mathrm{~L}^{1}\right)\left(\mathrm{CH}_{3} \mathrm{OH}\right)\right]^{2+}$ cation. Therefore, the corresponding bands of $\mathbf{1 a}^{*}$, containing the ligand in the most deprotonated form, are at lower wavelengths than for 1, exhibiting two bands at 416 and $349 \mathrm{~nm}$.

The addition of $\mathrm{Et}_{3} \mathrm{~N}$ to the methanolic solution of $\mathbf{1}$ resulted in the bands at 390 and $312 \mathrm{~nm}$. The spectrum of the obtained solution is different from the spectrum of the $\left[\mathrm{MoO}_{2}\left(\mathrm{~L}^{1}\right)\left(\mathrm{CH}_{3} \mathrm{OH}\right)\right]$ complex. However, it is similar to that of the deprotonated ligand $\left(\mathrm{L}^{1}\right)^{2-}$ obtained upon addition of $\mathrm{Et}_{3} \mathrm{~N}$ to the solution of $\mathrm{H}_{2} \mathrm{~L}^{1} \cdot \mathrm{HCl}$. Apparently, addition of $\mathrm{Et}_{3} \mathrm{~N}$ to the solution destabilizes the association between 
the ligand and the molybdenum atom, probably yielding the free doubly deprotonated ligand and the molybdate ion, $\mathrm{MoO}_{4}{ }^{2-}$. The same result was obtained also using $\mathrm{KOH}$ in methanol instead of $\mathrm{Et}_{3} \mathrm{~N}$.

The corresponding behaviour of compounds $\mathbf{2}$ and $\mathbf{3}$ is identical. In the case of $\mathbf{2}$, addition of $\mathrm{HCl}$ caused a shift of the 405 and $325 \mathrm{~nm}$ bands to 442 and $360 \mathrm{~nm}$, respectively. Similarly, the spectrum of 3 has absorption maxima at 427 and $342 \mathrm{~nm}$, whereas acidification with $\mathrm{HCl}$ shifted the bands to 438 and 361 nm, respectively.

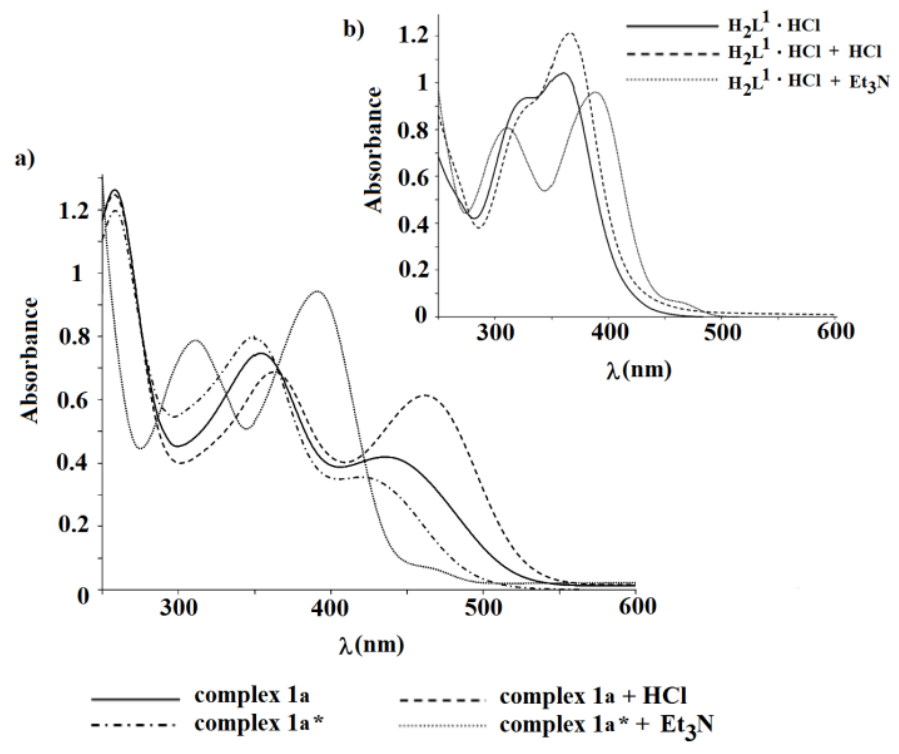

Figure 5. (a) UV-Vis spectra of thiosemicarbazone complexes $\left[\mathrm{MoO}_{2}\left(\mathrm{HL}^{1}\right)\left(\mathrm{CH}_{3} \mathrm{OH}\right)\right] \mathrm{Cl} \cdot 1.5 \mathrm{CH}_{3} \mathrm{OH}(\mathbf{1 a})$ and $\left[\mathrm{MoO}_{2}\left(\mathrm{~L}^{1}\right)\left(\mathrm{CH}_{3} \mathrm{OH}\right)\right] \cdot \mathrm{CH}_{3} \mathrm{OH}\left(\mathbf{1 a}^{*}\right)$ in methanol at $25^{\circ} \mathrm{C}$. (b) $\mathrm{UV}-\mathrm{V}$ is spectrum of $\mathrm{H}_{2} \mathrm{~L}^{1} \cdot \mathrm{HCl}$ in methanol at $25{ }^{\circ} \mathrm{C}$.

\subsection{Reactivity of Mo(VI) complexes towards oxygen acceptor: extension of the OAT reaction}

Reactions of dioxomolybdenum(VI) complexes 1-3 with triphenylphosphine $\left(\mathrm{PPh}_{3}\right)$ were performed in dry acetonitrile under an inert atmosphere and in the presence of $\gamma$-picoline to improve the solubility. OAT reactions resulted in the formation of dinuclear oxo-bridged molybdenum(V) complexes of general formula $\left[\mathrm{Mo}_{2}{ }_{2} \mathrm{O}_{3}\left(\mathrm{HL}^{1-3}\right)_{2}\right] \mathrm{Cl}_{2}$ (4-6) (Scheme 1), the nature of which was proven by chemical analyses, IR spectroscopy and TGA measurements.

The IR spectra of 4-6 exhibit bands around $950 \mathrm{~cm}^{-1}$ and $780 \mathrm{~cm}^{-1}$, assigned to terminal $\mathrm{Mo}=\mathrm{O}$ and Mo-O-Mo bridging groups, respectively (Figure S5 Supporting Information) [36]. All compounds were obtained pure with a $40 \%$ yield when the reaction proceeded for 10 hours. The diamagnetism, which is characteristic for oxo bridged $\mathrm{Mo}(\mathrm{V})$ dimers [37], was confirmed by magnetochemical measurements. Our results are consistent with findings reported by Young et al. [38]. As it has been previously shown, formation of $\left\{\mathrm{Mo}_{2}{ }_{2} \mathrm{O}_{3}\right\}^{4+}$ species from $\left\{\mathrm{Mo}^{\mathrm{VI}} \mathrm{O}_{2}\right\}^{2+}$ seems to be the result of OAT from $\left[\mathrm{Mo}^{\mathrm{VI}} \mathrm{O}_{2}\left(\mathrm{HL}^{1-}\right.\right.$ 
$\left.\left.{ }^{3}\right)\right] \mathrm{Cl}(\mathbf{1 - 3})$ to $\mathrm{PPh}_{3}[38,39]$. Weight losses corresponding to the complex decomposition were observed by TGA (under a pure oxygen atmosphere) in the $246-446{ }^{\circ} \mathrm{C}(4), 239-431{ }^{\circ} \mathrm{C}$ (5) and $223-448{ }^{\circ} \mathrm{C}(6)$ ranges, leading to $\mathrm{MoO}_{3}$.

The reactivity of complexes 4-6 towards oxygen donors is revealed by dissolution in DMSO, which leads to an immediate colour change from dark red to pale orange, as a consequence of the reoxidation to 1-3 [40]. For this reason, NMR spectra of these compounds could not be recorded. Unfortunately, all other attempts to characterize 4-6 were hampered by their poor solubility even in very polar solvents.

\subsection{Catalytic Epoxidation Reactions}

We have recently reported the catalytic activity of the neutral $\left[\mathrm{MoO}_{2}\left(\mathrm{~L}^{1}\right)(\mathrm{MeOH})\right](\mathbf{1 a})$ and $\left[\mathrm{MoO}_{2}\left(\mathrm{~L}^{1-3}\right)\right]_{\mathrm{n}}\left(\mathbf{1}^{*}-\mathbf{3}^{*}\right)$ complexes for the epoxidation of cyclooctene by aqueous TBHP (Scheme 4 and Scheme S1 in the Supporting Information) under solvent-free conditions and with a low Mo:olefin ratio $(1: 2000)$ [13]. We have now carried out a comparative study of the same catalytic reactions under the same conditions for the cationic complexes in 1-3 and 1a in order to evaluate and clarify the effect of ligand protonation.

Like the corresponding neutral complexes, the protonated analogues were sparingly soluble in cyclooctene and insoluble in water at room temperature, but completely dissolved in the organic phase after addition of aqueous TBHP at $80{ }^{\circ} \mathrm{C}$. The reactions were followed by ${ }^{1} \mathrm{H}$ NMR during 6 hours. The relevant results are summarized in Table 5 and the kinetic profiles are shown in Figure 6. The ligands alone were not active and the reference $\left[\mathrm{MoO}_{2}(\mathrm{acac})_{2}\right]$ (pre)catalyst gives a conversion of $54 \%$ with a $82 \%$ epoxide selectivity under these conditions [13].

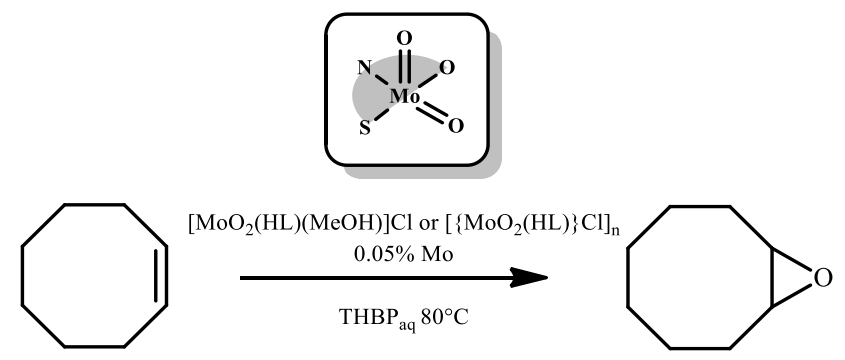

Scheme 4. General equation of Mo-catalyzed epoxidation of cyclooctene. 


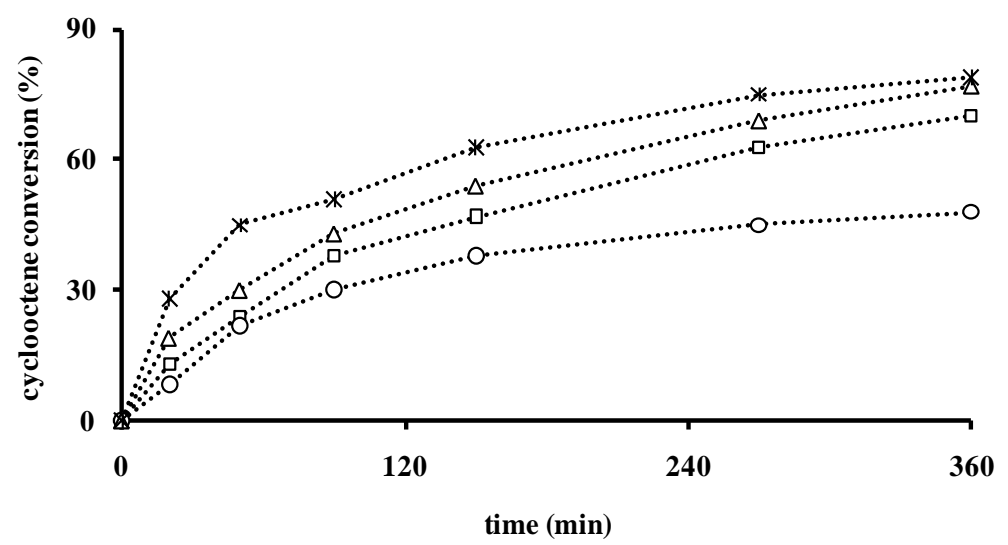

Figure 6. Converted cyclooctene vs. time with dioxomolybdenum(VI) (pre)catalysts: $\square \mathbf{1}, \bigcirc \mathbf{1 a}, \Delta \mathbf{2}, *$ 3. Conditions: $\mathrm{Mo} /$ substrate/TBHP $=1 / 2000 / 4000, \mathrm{~T}=80{ }^{\circ} \mathrm{C}$.

Table 5. Comparison of epoxidation data for dioxomolybdenum(VI) (pre)catalysts.

\begin{tabular}{cccccccccc}
\hline Complex & $\mathbf{1 a}$ & $\mathbf{1 a}^{*[13]}$ & $\mathbf{1}$ & $\mathbf{1} *[13]$ & $\mathbf{2}$ & $\mathbf{2}^{*[13]}$ & $\mathbf{3}$ & $\mathbf{3}^{*[13]}$ & [MoO2(acac)2 $^{[13]}$ \\
\hline Conversion $(\%)^{\mathrm{a}}$ & 48 & 97 & 70 & 54 & 78 & 71 & 79 & 69 & 54 \\
Selectivity $(\%)^{\mathrm{b}}$ & 74 & 97 & 82 & 84 & 86 & 92 & 89 & 99 & 82 \\
${\text { TOF }\left(\mathrm{h}^{-1}\right)^{\mathrm{c}}}^{4}$ & 480 & 3360 & 787 & 645 & 1080 & 960 & 1680 & 1080 & 530 \\
TON $^{\mathrm{d}}$ & 960 & 1940 & 1960 & 1040 & 1253 & 1420 & 1580 & 1380 & 1300
\end{tabular}

${ }^{\mathrm{a}}$ Calculated after $6 \mathrm{~h},{ }^{\mathrm{b}}$ formed epoxide per converted olefin after $6 \mathrm{~h},{ }^{\mathrm{c}}$ cyclooctene transformed / catalyst / time at 20 minutes, ${ }^{\mathrm{d}}$ cyclooctene transformed / catalyst at $6 \mathrm{~h}$

All compounds show relatively high selectivities (74-89\%) with moderate to very good conversions after $6 \mathrm{~h}(48-79 \%)$ in the order $1 \mathbf{a}<\mathbf{1}<\mathbf{2} \sim \mathbf{3}$. Surprisingly, the selectivity and the conversion with the mononuclear charged compound 1a are the lowest (even lower than for $\left[\mathrm{MoO}_{2}(\mathrm{acac})_{2}\right]$ ), at variance with the results obtained with the corresponding neutral $\mathrm{Mo}^{\mathrm{VI}}$ compound $1 \mathbf{a}^{*}$, where the mononuclear $\mathrm{MeOH}$ adduct performed better than the coordination polymers. The TON with $\mathbf{1}, \mathbf{2}$ and $\mathbf{3}(1960,1253$ and 1580) may be compared with those of the corresponding neutral systems (1040 for $1^{*}, 1420$ for $2^{*}$ and 1380 for $3^{*}$, respectively [13]). Hence, the ligand protonation has a strongly positive influence for $\mathrm{L}^{1}$, a moderately negative one in the case of $\mathrm{L}^{2}$ and a weakly positive one for $\mathrm{L}^{3}$. However, ligand protonation has a lower effect on the activity than methanol coordination. A visual comparison of the conversion and selectivity within the four complexes (mononuclear or polynuclear, neutral or cationic) containing ligand $\mathrm{L}^{1}$ is shown in Figure 7. All these results might be linked to the nature of the ligands, to the protonation state and to the energy required to remove methanol in case of mononuclear compounds. To our knowledge, under solvent-free conditions, neutral compounds with similar ligands and based on vanadium instead of molybdenum as the catalytic metalperformed less efficiently as greater metal 
loadings were required [41]. Several literature references concern the epoxidation of olefins using molybdenum containing complexes (1\% Mo vs. subsrate being the usual amount) with similar tridentate ligands as catalyst. Some of these catalysts exhibit very high TOF and are highly selective, but most of them were only used in solution of organic solvents (often dichloroethane) and/or with TBHP in decane as the oxidant [42]. The results presented herein are relevant because the process does not use solvent end employs TBHP in water as oxidant with a low catalysts loading.

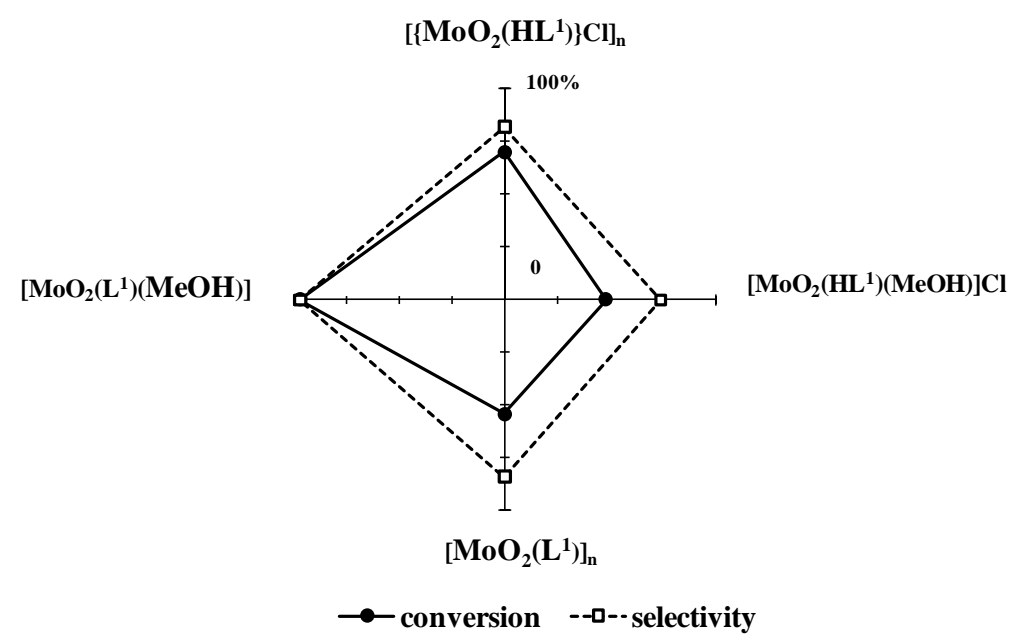

Figure 7. Conversion and selectivity comparison in epoxidation of cyclooctene by aqueous TBHP catalyzed by charged/neutral and/or monomeric/polymeric $\mathrm{Mo}{ }^{\mathrm{VI}}$ complexes synthesized from the $\mathrm{H}_{2} \mathrm{~L}^{1}$ ligand. The results for the neutral compounds are taken from ref [13].

\section{Conclusion}

Mononuclear and polynuclear charged molybdenum(VI) complexes with singly-deprotonated pyridoxal thiosemicarbazonato ligands have been synthesised and characterized. They have been used as precursors for the synthesis of corresponding dinuclear oxo-bridged molybdenum(V) complexes by reaction with $\mathrm{PPh}_{3}$. The catalytic activity has been tested for cyclooctene epoxidation by aqueous TBHP under solvent-free conditions. The emphasis was placed on very low Mo loading ( $0.05 \%$ vs. substrate). These compounds are quite active although generally not as much as the corresponding neutral analogues. Nevertheless, the results obtained with the charged polymeric materials provide a good basis for further optimization aiming at efficient catalyst recovery and recycling.

\section{Supporting Information}

Appendix A. Supplementary data - CCDC 829512 contains the supplementary crystallographic data for 1a. These data can be obtained free of charge via http://www.ccdc.cam.ac.uk/conts/retrieving.html, or 
from the Cambridge Crystallographic Data Centre, 12 Union Road, Cambridge CB2 1EZ, UK; fax: (+44) 1223-336-033; or e-mail: deposit@ccdc.cam.ac.uk.

\section{Acknowledgments}

All authors acknowledge the CNRS, the University Paul Sabatier (Institut Universitaire Paul Sabatier) and the Ministry of Science and Technology of the Republic of Croatia (Grant Nos. 119-1191342-1082 and 119-1193079-1084) for all research facilities. JP thanks the Ministry of Science and Technology of the Republic of Croatia, the National Foundation of Science and High Education of Croatia (03.01/O3511-2010) and the French Embassy in Croatia for a research fellowship.

\section{References}

[1] (a) E-Y. Choi, A. L. Stockert, S. Leimkühler, R. Hill, J. Inorg. Biochem. 98 (2004) 841-848;

(b) D. C. Rees, Y. Hu, C. Kisker, H. Schindelin, J. Chem. Soc., Dalton Trans. (1997) 3909-3914;

(c) Z. Xiao, M. A. Bruck, J. H. Enemark, C. G. Young, A. G. Wedd, Inorg. Chem. 35 (1996) 75087515

(d) M. A. Pietsch, M. B. Hall, Inorg. Chem. 35 (1996) 1273-1278;

(e) J. Topich, J. T. Lyon III, Inorg. Chem. 23 (1984) 3202-3206;

(f) R. H. Holm, Chem. Rev. 87 (1987) 1401-1449.

[2] (a) R. R. Mendel, Dalton Trans. (2005) 3404-3409;

(b) C. D. Brondino, M. J. Romão, I. Moura, J. J. G. Moura, Curr. Opin. Chem. Biol. 10 (2006) 109114 ;

(c) J. McMaster J. H. Enemark, Curr. Opin. Chem. Biol. 2 (1998) 109-114;

(d) A. Majumdar, S. Sarkar, Coord. Chem. Rev. 255 (2011) 1039-1054;

(e) R. Hille, T. Nishino, F. Bittner, Coord. Chem. Rev. 255 (2011) 1179-1205.

[3] (a) V. Vrdoljak, I. Đilović, M. Rubčić, S. Kraljević Pavelić, M. Kralj, D. Matković-Čalogović, I. Piantanida, P. Novak, A. Rožman, M. Cindrić, Eur. J. Med. Chem. 45 (2010) 38-48;

(b) G. Pelosi, F. Bisceglie, F. Bignami, P. Ronzi, P. Shiavone, M. C. Re, C. Casoli, E. Pilotti, J. Med. Chem. 53 (2010) 8765-8769;

(c) D. R. Richardson, D. S. Kalinowski, V. Richardson, P. C. Sharpe, D. B. Lovejoy, M. Islam, P. V. Bernhardt, J. Med. Chem. 52 (2009) 1459-1470;

(d) M. Belicchi Ferrari, F. Bisceglie, C. Casoli, S. Durot, I. Morgenstern-Badarau, G. Pelosi, E. Pilotti, S. Pinelli, P. Tarasconi, J. Med. Chem. 48 (2005) 1671-1675.

[4] (a) S. Floquet, M.C. Muñoz, R. Guillot, E. Rivière, G. Blain, J-A. Réal, M.-L. Boillot, Inorg. Chim. Acta 362 (2009) 56-64; 
(b) E. W. Y. Tido, C. Faulmann, R. Roswanda, A. Meetsma, P. J. van Koningsbruggen, Dalton. Trans. 39 (2010) 1643-1651.

[5] J. S. Casas, E. E. Castellano, M. C. Rodríguez-Argüelles, A. Sánchez, J. Sordo, J. Zukerman, Inorg. Chim. Acta 260 (1997) 183-188.

[6] U. Abram, K. Ortner, R. Gust, K. Sommer, J. Chem. Soc. Dalton Trans. (2000) 735-744.

[7] E. W. Y. Tido, G. O. R. A. van Ekenstein, A. Meetsma, P. J. van Koningsbruggen, Inorg. Chem. 47 (2008) 143-153.

[8] (a) M. Belicchi Ferrari, F. Bisceglie, G. Pelosi, P. Tarasconi, R. Albertini, P. P. Dall'Aglio, S. Pinelli, A. Bergamo, G. Sava, J. Inorg. Biochem. 98 (2004) 301-312;

(b) K. Aoki, N. Hu, H. Yamazaki, Inorg. Chim. Acta 186 (1991) 253-261;

(c) E. W. Y. Tido, E. J. M. Vertelman, A. Meetsma, P. J. van Koningsbruggen, Inorg. Chim. Acta 360 (2007) 3896-3902.

[9] (a) S. Taktak, W. Ye, A. M. Herrera, E. V. Rybak-Akimova, Inorg. Chem. 46 (2007) 2929-2942;

(b) M. Haga, M. Ali, S. Koseki, K. Fujimoto, A. Yoshimura, K. Nozaki, T. Ohno, K. Nakajima, D. Stufkens, Inorg. Chem. 35 (1996) 3335-3347;

(c) S. Klein, W. G. Dougherty, W. S. Kassel, T. J. Dudley, J. J. Paul, Inorg. Chem. 50 (2011) 27542763.

[10] (a) E. W. Y. Tido, G. O. R. A van Ekenstein, A. Meetsun, P. van Koningsbruggen, Inorg. Chem. 47 (2008) 143-153;

(b) M. B. Ferrari, G. G. Fava, C. Pelizzi, P. Tarasconi, G. Tosi, J. Chem. Soc., Dalton Trans. (1987) 227-233;

(c) M. B. Ferrari, G. G. Fava, M. Lanfranchi, C. Pelizzi, P. Tarasconi, J. Chem. Soc., Dalton Trans. (1991) 1951-1957;

(d) V. M. Leovac, L. S. Jovanović, V. S. Jevtović, G. Pelosi, F. Bisceglie, Polyhedron 26 (2007) 2971-2978.

[11] V. Vrdoljak, J. Pisk., B. Prugovečki, D. Matković-Čalogović, Inorg. Chim. Acta 362 (2009) 40594064.

[12] (a) P. M. Reis, C. A. Gamelas, J. A. Brito, N. Saffon, M. Gomez, B. Royo, Eur. J. Inorg. Chem. 5 (2011) 666-673;

(b) C. Dinoi, M. Ciclosi, E. Manoury, L. Maron, L. Perrin, R. Poli, Chem. Eur. J. 16 (2010) 95729584;

(c) K. A. Jorgensen, Chem. Rev. 89 (1989) 431-485.

[13] J. Pisk, D. Agustin, V. Vrdoljak, R. Poli, Adv. Synth. Catal.353 (2011) 2910-2914.

[14] A. I. Vogel, Textbook of Quantitative Inorganic Analysis, 5th ed., Longman Group Ltd., London, (1989) 480-481. 
[15] G. J.-J. Chen, J. W. McDonald, W. E. Newton, Inorg. Chem. 15 (1976) 2612-2615.

[16] M. Belicchi Ferrari, G. Gasparri Fava, C. Pelizzi, G. Pelosi, P. Tarasconi, Inorg. Chim. Acta, 269 (1998) 297-301.

[17] Oxford Diffraction, Oxford Difraction Ltd., Xcalibur CCD system, CRYSALIS Software system, Version 1.170, (2003).

[18] L. J. Farrugia, J. Appl. Crystallogr. 32 (1999) 837-838.

[19] G. M. Sheldrick, Acta Cryst. Sect. A 64 (2008) 112.

[20] G. M. Sheldrick, SHELXL-97, Program for the Refinement of Crystal Structures, University of Göttingen, Germany, (1997).

[21] (a) A. L. Spek, Acta Crystallogr., Sect. A 46 (1990) C34;

(b) A. L. Spek, PLATON: A Multipurpose Crystallographic Tool; Utrecht University: Utrecht, The Netherlands, (1998).

[22] C. F. Macrae, P. R. Edgington, P. McCabe, E. Pidcock, G. P. Shields, R. Taylor, M. Towler, J. Van der Streek, J. Appl. Crystallogr. 41 (2008) 466-470.

[23] M. J. Frisch, G. W. Trucks, H. B. Schlegel, G. E. Scuseria, M. A. Robb, J. R. Cheeseman, J. Montgomery, J. A., T. Vreven, K. N. Kudin, J. C. Burant, J. M. Millam, S. S. Iyengar, J. Tomasi, V. Barone, B. Mennucci, M. Cossi, G. Scalmani, N. Rega, G. A. Petersson, H. Nakatsuji, M. Hada, M. Ehara, K. Toyota, R. Fukuda, J. Hasegawa, M. Ishida, T. Nakajima, Y. Honda, O. Kitao, H. Nakai, M. Klene, X. Li, J. E. Knox, H. P. Hratchian, J. B. Cross, C. Adamo, J. Jaramillo, R. Gomperts, R. E. Stratmann, O. Yazyev, A. J. Austin, R. Cammi, C. Pomelli, J. W. Ochterski, P. Y. Ayala, K. Morokuma, G. A. Voth, P. Salvador, J. J. Dannenberg, V. G. Zakrzewski, S. Dapprich, A. D. Daniels, M. C. Strain, O. Farkas, D. K. Malick, A. D. Rabuck, K. Raghavachari, J. B. Foresman, J. V. Ortiz, Q. Cui, A. G. Baboul, S. Clifford, J. Cioslowski, B. B. Stefanov, G. Liu, A. Liashenko, P. Piskorz, I. Komaromi, R. L. Martin, D. J. Fox, T. Keith, M. A. Al-Laham, C. Y. Peng, A. Nanayakkara, M. Challacombe, P. M. W. Gill, B. Johnson, W. Chen, M. W. Wong, C. Gonzalez, J. A. Pople, Gaussian 03, Revision D.01, Gaussian, Inc., Wallingford CT, (2004).

[24] (a) A. D. Becke, J. Chem. Phys. 98 (1993) 5648-5652;

(b) C. T. Lee, W. T. Yang, R. G. Parr, Phys. Rev. B 37 (1988) 785-789;

(c) B. Miehlich, A. Savin, H. Stoll, H. Preuss, Chem. Phys. Lett. 157 (1989) 200-206.

[25] (a) R. Ditchfield, W. J. Hehre, J. A. Pople, J. Chem. Phys. 54 (1971) 724-728;

(b) W. Hehre, R. Ditchfield, J. Pople, J. Chem. Phys. 56 (1972) 2257-2261;

(c) P. C. Hariharan, J. A. Pople, Theor. Chim. Acta 28 (1973) 213-222;

(d) P. C. Hariharan, J. A. Pople, Mol. Phys. 27 (1974) 209-214.

[26] (a) W. J. Stevens, H. Basch, M. Krauss, J. Chem. Phys. 81 (1984) 6026-6033;

(b) W. J. Stevens, M. Krauss, H. Basch, P. G. Jasien, Can. J. Chem. 70 (1992) 612-630; 
(c) T. R. Cundari, W. J. Stevens, J. Chem. Phys. 98 (1993) 5555-5565.

[27] O. A. Rajan, A. Chakratvorty, Inorg. Chem. 20 (1981) 660-664.

[28] M. R. Maurya, S. Gopinathan, C. Gopinathan, Polyhedron 12 (1993) 159-163.

[29] (a) K. Nakajima, K. Yokoyama, T. Kano, M. Kojima, Inorg. Chim. Acta 282 (1998) 209-216;

(b) J. M. Berg, R. H. Holm, Inorg. Chem. 22 (1983) 1768-1771.

[30] M. Ferrari Belicchi, G. Fava Gasparri, E. Leporati, C. Pelizzi, P. Tarasconi, G. Tosi, J. Chem. Soc. Dalton Trans. (1986) 2455-2461.

[31] M. R. Maurya, A. Kumar, M. Abid, A. Azam, Inorg. Chim. Acta 359 (2006) 2439-2447.

[32] (a) V. Vrdoljak, B. Prugovečki, D. Matković-Čalogović, J. Pisk, CrystEngComm 13 (2011) 43824390 ;

(b) V. Vrdoljak, B. Prugovečki, D. Matković-Čalogović, J. Pisk, R. Dreos, P. Siega, Cryst. Growth Des. 11 (2011) 1244-1252.

[33] V. Vrdoljak, B. Prugovečki, D. Matković-Čalogović, R. Dreos, P. Siega, C. Tavagnacco, Cryst. Growth Des. 10 (2010) 1373-1382.

[34] M. Nishiki, W. Oi, J. Ito, J. Inc. Phenom. Macrocycl. Chem. 61 (2008) 61-69.

[35] S. Purohit, A. P. Koley, L. S. Prasad, P. T. Manoharan, S. Ghosh, Inorg. Chem. 28 (1989) 37353742.

[36] H. Arzoumanian, R. Bakhtchadjian, R. Atencio, A. Briceno, G. Verde, G. Agrifoglio, J. Mol. Catal. A: Chem. 260 (2006) 197-201.

[37] (a) S. Lincoln, S. A. Koch, Inorg. Chem. 25 (1986) 1594-1602;

(b) K. Heinze, A. Fischer, Eur. J. Inorg. Chem. (2010) 1939-1947 .

[38] C. J. Doonan, D. A. Slizys, C. Young, J. Am. Chem. Soc. 121 (1999) 6430-6436.

[39] (a) K. Heinze, G. Marano, A. Fischer, J. Inorg. Biochem. 102 (2008) 1199-1211;

(b) V. Vrdoljak, D. Milić, M. Cindrić, D. Matković-Čalogović, J. Pisk, M. Marković, P. Novak, Z. Anorg. Allg. Chem. 635 (2009) 1242-1248.

[40] X. Ma, C. Schulzke, Z. Yang, A. Ringe, J. Magull, Polyhedron 26 (2007) 5497-5505.

[41] C. Cordelle, D. Agustin, J.-C. Daran, R. Poli, Inorg. Chim. Acta 364 (2010) 144-149.

[42] (a) P. Neves, S. Gago, S. S. Balula, A. D. Lopes, A. A. Valente, L. Cunha-Silva, F. A. Almeida Paz, M. Pillinger, J. Rocha, C. M. Silva, I. S. Gonçalves, Inorg. Chem. 50 (2011) 3490-3500;

(b) P. M. Reis, C. A. Gamelas, J. A. Brito, N. Saffon, M. Gomez, B. Royo, Eur. J. Inorg. Chem. (2011) 666-673;

(c) A. C. Coelho, M. Nolasco, S. S. Balula, M. M. Antunes, C. C. L. Pereira, F. A. Almeida Paz, A. A. Valente, M. Pillinger, P. Ribeiro-Claro, J. Klinowski, I. S. Gonçalves, Inorg. Chem. 50 (2011) $525-538$; 
(d) A. Guenyar, D. Betz, M. Drees, E. Herdtweck, F. E. Kühn, J. Mol. Catal. A: Chem. 331 (2010) 117-124;

(e) A. Rezaeifard, I. Sheikhshoaie, N. Monadi, M. Alipour, Polyhedron 29 (2010) 2703-2709;

(f) Y.-D. Li, X.-K. Fu, B.-W. Gong, X.-C. Zou, X.-B. Tu, J.-X. Chen, J. Mol. Catal. A: Chem. 322 (2010) 55-62;

(g) M. Abrantes, P. Neves, M. M. Antunes, S. Gago, F. A. Almeida Paz, A. E. Rodrigues, M. Pillinger, I. S. Gonçalves, C. M. Silva, A. A. Valente, J. Mol. Catal. A: Chem. 320 (2010) 19-26;

(h) M. Moghadam, V. Mirkhani, S. Tangestaninejad, I. Mohammadpoor-Baltork, M. M. Javadi, Polyhedron 29 (2010) 648-654;

(i) S. Gago, S. S. Balula, S. Figueiredo, A. D. Lopes, A. A. Valente, M. Pillinger, I. S. Gonçalves, Appl. Catal., A 372 (2010) 67-72;

(j) M. Bagherzadeh, L. Tahsini, R. Latifi, Reza; L. K. Woo, Inorg. Chim. Acta 362 (2009) 36983702 ;

(k) X. Zhou, J.Zhao, A. M. Santos, F. E. Kühn, Z Naturforsch, B: Chem. Sci. 59 (2004) 1223-1228;

(1) A. Rezaeifard, I. Sheikhshoaie, N. Monadi, H. Stoeckli-Evans, Eur. J. Inorg. Chem. (2010) 799806;

(m) S. N. Rao, N. Kathale, N. N. Rao, K. N. Munshi, Inorg. Chim. Acta 360 (2007) 4010-4016;

(n) Y. Sui, X. Zeng, X. Fang, X. Fu, Y. Xiao, L. Chen, M. Li, S. Cheng, J. Mol.Catal. A: Chem. 270 (2007) 61-67;

(o) S. Bellemin-Laponnaz, K. S. Coleman, P. Dierkes, J.-P. Masson, J. A. Osborn, Eur. J. Inorg. Chem. (2000) 1645-1649;

(p) Y.-L.Wong, D. K. P. Ng, H. K. Lee, Inorg. Chem. 41 (2002) 5276-5285;

(q) J. M. Sobczak, J. J. Ziołkowski, Appl. Catal. A 248 (2003) 261-268. 